\title{
Anastrozole and Levonorgrestrel-Releasing Intrauterine Device in the Treatment of Endometriosis: A Randomized Clinical Trial.
}

Pedro Acién ( $\square$ acien@umh.es)

Emeritus Professor https://orcid.org/0000-0002-5773-1862

Irene Velasco

Hospital Universitari Sant Joan d'Alacant

Maribel Acién

Hospital Universitari Sant Joan d'Alacant

Research article

Keywords: Aromatase inhibitors, Anastrozole, levonorgestrel-IUD, endometriosis, endometriomas, clinical trial

Posted Date: December 28th, 2020

DOI: https://doi.org/10.21203/rs.3.rs-51837/v4

License: (c) (i) This work is licensed under a Creative Commons Attribution 4.0 International License. Read Full License

Version of Record: A version of this preprint was published at BMC Women's Health on May 20th, 2021. See the published version at https://doi.org/10.1186/s12905-021-01347-9. 


\section{Abstract}

Background: To study the effectiveness of an aromatase inhibitor (Anastrozole) associated to levonorgestrel-releasing intrauterine device (LNG-IUD, Mirena $\left.{ }^{\circledR}\right)$ in the treatment of endometriosis.

Methods: Prospective, randomized clinical trial. Setting: University Hospital (single center). Elegibility criteria: Endometriomas $>3 \times 4 \mathrm{~cm}, \mathrm{CA}-125>35 \mathrm{U} / \mathrm{mL}$ and endometriosis symptoms. Patients: Thirty-one women randomized to anastrozole+Mirena ${ }^{\circledR}+$ Conservative Surgery $(\mathrm{CS})(\mathrm{n}=8)$, anastrozole+Mirena ${ }^{\circledR}+$ transvaginal ultrasound-guided puncture-aspiration (TUGPA) $(n=7)$, Mirena ${ }^{\circledR}+C S$ $(n=9)$, or Mirena ${ }^{\circledR}+$ TUGPA $(n=7)$. Interventions: Anastrozole $1 \mathrm{mg} /$ day and/or only Mirena ${ }^{\circledR}$ for 6 months; CS (ovarian and fertility-sparing) or TUGPA of endometriomas one month after starting medical treatment. Main Outcome Measures: Visual analogic scale for symptoms, CA-125 levels, ultrasound findings of endometriomas and recurrences.

Results: A significant improvement in symptoms during the treatment (difference of $43 \%, 95 \% \mathrm{Cl} 29.9$ 56.2) occurred, which was maintained at 1 and 2 years. It was more significant in patients treated with anastrozole (51\%, 95\% Cl 33.3-68.7). For CA-125, the most significant decrease was observed without anastrozole (73.8\%, 95\% Cl 64.2-83.4 vs. $53.8 \%, 95 \% \mathrm{Cl} 25.7-81.6$ under Mirena ${ }^{\circledR}+$ tanastrozole). After CS for endometriosis, a reduction of findings of endometriomas and long-term recurrences occurred, with or without anastrozole. At 4,2 21,7 years $(95 \% \mathrm{Cl} 3,57-4,85), 88 \%$ of the patients who underwent CS were asymptomatic, without medication or reoperation, compared to only $21 \%$ if TUGPA was performed, with or without anastrozole $(\mathrm{p}=0.019)$.

Conclusions: Dosing anastrozole for 6 months, starting one month before CS of endometriosis, reduces more significantly the painful symptoms and delays recurrences, but has no other significant advantages over the single insertion of LNG-IUD (Mirena ${ }^{\circledR}$ ) during the same time. Anastrozole and/or only Mirena ${ }^{\circledR}$ associated with TUGPA are not effective.

\section{Highlights}

1. Anastrozole and LNG-IUD for 6 months improve significantly the painful symptoms of endometriosis.

2. However, Anastrozole has no significant advantages over the single insertion of LNG-IUD (Mirena) ${ }^{\circledR}$ ).

3. Anastrozole and/or Mirena ${ }^{\circledR}$ associated with puncture-aspiration of endometriomas are not very effective.

\section{Plain English Summary}

This was a randomized CT designed to study the effectiveness of an aromatase inhibitor (Anastrozole) associated to levonorgestrel-releasing intrauterine device (LNG-IUD, Mirena ${ }^{\circledR}$ ) in the treatment of endometriosis. The eligibility criteria were presence of endometriomas $>3 \times 4 \mathrm{~cm}$ (ultrasound), CA-125 
values $>35 \mathrm{U} / \mathrm{mL}$ and endometriosis symptoms assessed with a VAS $>4$; and these being the main outcome measures in addition to recurrences. The interventions were 1) administration of Anastrozole 1 $\mathrm{mg} /$ day and/or Mirena ${ }^{\circledR}$ for 6 months; and 2 ) to perform conservative surgery (CS, ovarian and fertilitysparing) or transvaginal ultrasound-guided puncture-aspiration (TUGPA) of endometriomas, one month after starting medical treatment.

Thirty-one women were randomized to anastrozole+Mirena ${ }^{\circledR}+C S(n=8)$, anastrozole+Mirena ${ }^{\circledR}+$ TUGPA $(n=7)$, Mirena ${ }^{\circledR}+C S(n=9)$, or Mirena ${ }^{\circledR}+\operatorname{TUGPA}(n=7)$. The results showed a significant improvement in symptoms during the treatment which was maintained at 1 and 2 years and that was more significant in patients treated with anastrozole, although for CA-125, the most significant decrease was observed without anastrozole. After CS, a reduction of findings of endometriomas and long-term recurrences occurred, with or without anastrozole. At $4.2 \pm 1.7$ years, $88 \%$ of the patients who underwent CS were asymptomatic, without medication or reoperation, compared to only $21 \%$ if TUGPA was performed, with or without anastrozole.

In conclusion, dosing anastrozole for 6 months, starting one month before CS of endometriosis, reduces more significantly the painful symptoms and delays recurrences, but has no other significant advantages over the single insertion of LNG-IUD (Mirena ${ }^{\circledR}$ ) during the same time. However, the medical treatments associated with TUGPA are not effective.

\section{Background}

The therapeutic perspectives for endometriosis have been directed in the last years towards the use of a variety of new medications including immunomodulatory agents (i.e. local interleukin-2r [1]), selective estrogen and progesterone receptor modulators, GnRH antagonist, angiogenic inhibitors, or the thirdgeneration aromatase inhibitors (AI) (i.e. Anastrozole and Letrozole), systemically and/or locally administered, and eventually without the need for surgery [2, 3-5]. Anastrozole inhibits aromatase and decreases the amount of estrogens in all tissues; thus, in positive aromatase endometriotic implants, it should prevent local estrogenic production and, therefore, endometriotic tissue proliferation [2, 6-8]. That estrogen suppression and subsequent response from the adenohypophysis could lead to an increase in gonadotropins with consequent ovarian stimulation and possible formation of dysfunctional cysts or eventual follicular rupture, ovulation, and pregnancy. Thus, in all studies in premenopausal women with endometriosis in which long-term Als have been used, they have been associated with gonadotropinreleasing hormone $(\mathrm{GnRH})$ analogues, to slow down gonadotropins and produce hypoestronism, or with progestins or oral contraceptive pills (OCP), which could also improve endometriosis and its symptoms. An alternative as a contraceptive method could be the use of a levonorgestrel-releasing intrauterine device (LNG-IUD), such as Mirena ${ }^{\circledR}$, a device that contains $52 \mathrm{mg}$ of levonorgestrel (LNG) and releases it in situ $20 \mu \mathrm{g} / 24$ hours. LNG induces the atrophia of eutopic endometrium that would reduce or avoid the retrograde menstruation. Based on previous reports about the use of both medications (Anastrozole [3, 4] and MirenaÒ [9]) in endometriosis patients, our therapeutical proposal was to associate Anastrozole administered orally for 6 months with Mirena ${ }^{\circledR}$ during the same time period. Furthermore, although this 
medical treatment (Anastrozole and/or only Mirena) could be more effective when associated to the surgical exeresis of the endometriotic foci, we wanted to clarify whether this would also be the case when associated to transvaginal ultrasound-guided puncture-aspiration (TUGPA) of the endometriomas, as we had already done in previous works associating TUGPA with analogues or leaving r-IL2 in situ $[1,10,11]$.

Study objective: We proposed a clinical trial (CT), whose main objective was to assess the efficacy of Al Anastrozole associated with LNG-IUD (Mirena $\left.{ }^{\circledR}\right)$ (compared with Mirena ${ }^{\circledR}$ alone), in the treatment of moderate and severe endometriosis and its symptoms, along with laparoscopic or laparotomic conservative surgery (CS) (ovarian and fertility-sparing), or with simple TUGPA of the endometriomas.

\section{Methods}

Study design. Randomized, comparative and controlled clinical trial (CT) whose protocol (ENDOMET-IADIULNG08) was approved by the Ethics Committee of San Juan University Hospital (26-August-2008). It was registered in the Eudra CT System of the European Medicines Agency (London, 29-Sept-2008; № EudraCT: 2008-005744-17) (07/11/2008) and then authorized by the Spanish Agency for Medicines and Health Products (AEMPS) (10/11/2008).

Participants: Premenopausal women with endometriomas recruited at the Endometriosis and Reproductive Medicine Consultation of San Juan University Hospital. They had been advised for CS, did not currently desire pregnancy, and accepted the insertion of LNG-IUD (Mirena ${ }^{\circledR}$ ) for 6 months and randomization to perform conservative surgery (CS) with ovarian and fertility-sparing by laparoscopy or laparotomy, or only transvaginal ultrasound-guided puncture-aspiration (TUGPA) of endometriomas, 1 month after the IUD insertion.

Inclusion criteria: Young women ( $<41 \mathrm{y}$ ) with significant clinical symptoms (score of visual analogue scale (VAS) $\geq 4)$, elevated CA-125 ( $\geq 35 \mathrm{U} / \mathrm{mL}$ ), and a transvaginal ultrasound (TVU) with suggestive findings of endometriomas $(>3 \times 4 \mathrm{~cm}$ ). These patients could have a previous diagnosis and treatment (medical and/or surgical) of endometriosis, but they should not have received medical treatment in the last 3 months.

Exclusion criteria: i) Pregnancy; ii) Infertility with current desire for pregnancy; iii) No previous sexual intercourse and/or non-acceptance of insertion of Mirena ${ }^{\circledR}$; iv) Acute or recurrent pelvic inflammatory disease or genital tract infection; v) Uterine malformations and/or leiomyomas; vi) Any medical pathology that could contraindicate the treatment with Anastrozole or LNG-IUD (Mirena®).

Written informed consent was obtained from all patients before randomization. Participants were randomized by computer, determined at the Hospital Pharmacy after a telephone call from the Endometriosis Consultation. Between January 15, 2009 (date of inclusion of the first patient) and March 15,2015 , the eligibility criteria were analyzed in 52 patients who had ovarian cystic tumors suggestive of endometriomas, with indication to CS. After excluding 21 patients due to not meeting all the inclusion criteria, doubts in the ultrasound diagnosis, or because they declined to participate, the other 31 women 
were included, randomized, treated and followed up according to the following subgroups: (1) Anastrozole-Mirena-CS ( $n=8)$; (2) Anastrozole-Mirena-TUGPA ( $n=7)$; (3) no Anastrozole-Mirena-CS ( $n=$ 9); and (4) no Anastrozole-Mirena-TUGPA ( $n=7)$.

Procedures. Medical treatments: (1) oral Anastrozole, 1 tablet of $1 \mathrm{mg}$ daily for 6 months administered to patients in subgroups 1 and 2; (2) LNG-IUD (Mirena®) for all patients; (3) calcium carbonate and cholecalciferol $(\mathrm{Ca}+\mathrm{Vitamin} \mathrm{D})$ to patients taking Anastrozole to avoid the damaging effects of Al on the bone. Surgical treatments: (1) laparoscopy (in 13 women, 76\%) or laparotomy (in 4 women -in 2 was conversion-) with CS of endometriosis; or (2) TUGPA of endometriomas (in 14 women). All surgeries were performed or directed by the first author of the present study (PA).

Research plan: All patients will undergo a first analytical control, clinical exploration and TVU in the second half of the cycle, being randomized according to the subgroups previously exposed. Patients of subgroups 1 and 2 would start taking Anastrozole at the beginning of the next menstruation, placing the LNG-IUD (Mirena ${ }^{\circledR}$ ) during it, as well as in the other subgroups. At the time, the surgical proposal to be practiced a month later was processed. Postoperative control follow-ups would be done at 3 and 6 months (time of withdrawal of Anastrozole and Mirena ${ }^{\circledR}$ ); thereafter at 9, 12, 18, 24 months, and then annual follow-ups.

Assessments. All patients must have a detailed medical history about their antecedents and previous treatments, also including clinical exploration, TVU, hormonal and tumor marker analysis (CA-125, CA-199) and symptoms score using our VAS [maximum 10 points, including dysmenorrhea (0-3), deep dyspareunia (0-3), chronic pelvic pain (CPP, 0-3), and others (0-1)]. In all subsequent follow-ups, TVU, analysis and VAS score for symptoms were repeated.

We considered recurrence of the disease when an endometrioma was detected in any control, which persisted or grew in subsequent follow-ups, associated with an increase in VAS score and/or CA-125 level. In any case, the recurrences of small endometriomas $(1.5-3 \mathrm{~cm})$ and endometriomas greater than $3 \times 4 \mathrm{~cm}$ are presented separately in the tables of results.

Outcomes. Primary endpoint. clinical, analytical and ultrasound improvement assessed by (1) reduction or disappearance of symptoms; (2) normalization of CA-125 values; (3) reduction or disappearance of endometriomas. These parameters were studied in each postoperative control follow-up at 3 and 6 months; thereafter at 9, 12, 18, 24 months, and then in annual follow-ups. Secondary endpoints: (1) decrease or disappearance of recurrences; (2) rate of reoperations; (3) subsequent pregnancy achievement; and (4) valuation of the clinical state in the last follow-up and the need for other treatments.

Safety and adverse events. In laparoscopic or laparotomic surgery, peritoneal fluid and biopsies or surgical specimens were collected for cytological and histopathological studies. In TUGPA, endometrioma fluids were also collected for cytological analysis. Side effects and adverse events were registered and considered in each patient follow-up. 
Statistical analysis. Sample size: Based on previously published studies using AI [3,4,12,13] or LNG-IUD [9], in the research project-protocol of the clinical trial ENDOMET-IA-DIULNG08 (EudraCT No.: 2008005744-17) we include the following analysis: "with respect to symptoms, with the LNG-IUD we expect to find improvements of $60 \%$ and, with associating aromatase inhibitors + LNG-IUD, of $94 \%$ ( $p<0.05$ with 16 cases in each branch). Regarding recurrence of symptoms and endometriosis, after LNG-IUD it would be foreseeable that only $20-25 \%$ will be free of recurrence in two years, while with aromatase inhibitors + LNG-IUD, more than $60 \%$ may be free ( $p<0.01$ with 24 cases in each branch) ". Therefore, we estimated a total sample size of 48 patients (12 in each subgroup) to study in a period of 3 years, which was prolonged another 3 years due to difficulties for recruitment. However, we decided to finish it in March 2015 due to its low rate, to the need to make a final report in September-2015 and also because the patients undergoing TUGPA were not showing good clinical results. Nevertheless, their follow-up continued to the final data collection in July-2017.

All data were entered into SPSS Statistics version 25.0 (IBM, Spain) to perform statistical analysis. Data are expressed as percentages, mean \pm standard deviation (SD), median, minimum and maximum (minmax) values, and a 95\% confidence interval (CI) (if applicable). The main dependent variables were the VAS score, the absence or presence of endometriomas in TVU, and the values of CA-125, as well as their evolution in later follow-ups. The main independent variables were Anastrozole+LNG-IUD or only LNG-IUD treatments, as well as CS or TUGPA of endometriomas. We applied descriptive statistical analysis for qualitative variables to determine frequencies and distribution using contingency tables and comparison of proportions. The chi-squared, Kruskal-Wallis, Mann-Whitney $\mathrm{U}$ and correlation tests were used to compare groups and parameters in the different follow-ups. For quantitative or numerical variables, we applied nonparametric tests for paired data to compare the values before and at 3,6 , and 9 months, and 1 and 2 years, and the last follow-up after treatment, calculating the Wilcoxon signed rank test, the signs test, the McNemar test (for dichotomous variants), and the marginal homogeneity test, noting in tables and graphs only the significant results. Likewise, nonparametric tests were applied to compare Anastrozole and non-Anastrozole groups. To determine the recurrence and reoperation rates, we calculated the percentage accumulated every 3 months up to 2 years, and then every year up to 6 years, pointing at the corresponding figures the patients at risk in each period, subtracting recurrences and loss to follow-up. All $p$ values reported are 2 -tailed, and $p<0.05$ was considered significant.

\section{Results}

Participants recruited and included in the study. The eligibility criteria were analyzed in 52 patients (see Fig. 1). After excluding 21 patients, 31 women were included in the CT and randomized in the 4 subgroups mentioned above. All patients had a LNG-IUD (Mirena ${ }^{\circledR}$ ) for 6 months, and 15 of them also received Anastrozole for the same period. The latter were followed for $4.67 \pm 1.63$ years ( $95 \% \mathrm{Cl}$ : 3.76 5.57 ), and the first ones for $3.78 \pm 1.77$ years ( $95 \% \mathrm{Cl}: 2.84-4.72)$, without significant differences.

Baseline characteristics. Table 1 shows the characteristics, antecedents, symptoms, laboratory tests, and ultrasound and operative findings of the four subgroups of patients. No significant differences were 
observed.

Primary outcomes. The evolution of the primary efficacy variables, up to 2 years, in the four studied groups is showed in Table 2. In the Anastrozole groups, especially in +CS, the VAS values (mainly dysmenorrhea) were significantly reduced and kept low. Similar results were observed in the levels of tumor markers and the recurrence of endometriomas, but differences were not significant if +TUGPA was performed. The reduction of VAS (dysmenorrhea and dyspareunia), CA-125, and endometriomas was equally significant in patients treated with LNG-IUD + CS without Anastrozole. CA-125 level also decreased significantly in the LNG-IUD + TUGPA - No Anastrozole group.

A more detailed assessment of this evolution is represented in Fig. 2 (and in Fig. 3), according to the patients who took or not Anastrozole (in follow-up results, the re-operated cases were excluded). Fig. 2 represents the evolution of the symptoms scaled over 10 (absolute value of the VAS), as well as the evolution of dysmenorrhea, dyspareunia, and CPP scaled over 3 . The most significant improvements were for dysmenorrhea and CPP during the taking of Anastrozole. Fig. 3a shows that the percentage of reduction or improvement of the VAS score is more significant at 3 and 6 months, with or without Anastrozole, maintaining similar values during the follow-up period. On average, there was a significant improvement of symptoms during (difference 44\%,95\% Cl: 27.7-60.4) and after treatment at 6 months (43\%, 95\%Cl: 29.9-56.2), which is maintained at follow-ups of 1 year (31\%, 95\% Cl: 17.6-44.4) and 2 years (43.7\%, 95\%Cl: 27.7-59.6). This improvement was more significant in those patients who had taken Anastrozole (at 3 months: $57 \%, 95 \% \mathrm{Cl}: 40.3-73.4$; at 6 months: 51\%, 95\% Cl: 33.3-68.7; at 1 year: $44.5 \%$, 95\%Cl: 28-61; and at 2 years: $51.3 \%, 95 \% \mathrm{Cl}$ : 31.6-71). There are, however, no significant differences between Anastrozole and non-Anastrozole, except for at the 1-year follow-up (Mann-Whitney U test, $p=$ $0.048)$.

Regarding levels of CA-125 (Fig. 3b), we observed a significant reduction, similar to that of the VAS score, but only in those patients who did not take Anastrozole, in both the absolute values and the percentage of cases with high level of this marker $(>35 \mathrm{U} / \mathrm{mL})$, at least up to 1 year. In these patients, the decrease of CA-125 values was $64 \%(95 \% \mathrm{Cl}: 40.8-87.3)$ at 3 months and $73.8 \%(95 \% \mathrm{Cl}: 64.2-83.4)$ at 6 months versus 49.6\% (95\% Cl: $19.6-79.7)$ and 53.8\% (95\% Cl: $25.7-81.6)$, respectively, in patients treated with Anastrozole + Mirena ${ }^{\circledR}$.

The sonographic findings showed a similar behaviour (Fig. 3cd), with an increase of recurrent endometriomas until 9 months to 1 year that decreased when some patients were re-operated, but no significant differences were observed between Anastrozole and non-Anastrozole.

Secondary outcomes. Fig. 4 shows the recurrence and reoperation rates observed during a 6-year followup period. Although the recurrence rate was similar at 2 years with or without Anastrozole (50\%), the use of this Al delayed their appearance; however, differences were not statistically significant. In groups 1 and 3 , both with Mirena ${ }^{\circledR}+C S$, there were few recurrences, with simple cysts or small endometriomas. However, in patients treated with Mirena ${ }^{\circledR}+$ TUGPA (groups 2 and 4), the endometriomas increased 
(together with reoperations) when the LNG-IUD was removed (see table 2). Lines of the cumulative percentage of reoperations were also similar with or without Anastrozole.

Fertility and clinical status of patients in the last control are shown in Table 3 . Ten percent of them got pregnant and a $13 \%$ remained infertile. At $4.2 \pm 1.7$ years of follow-up $(95 \% \mathrm{Cl}$ : $3.57-4.85$; median 4 years, range $1-7$ years), $25 \%$ of cases were reoperated, $13 \%$ showed persistent endometriosis (although these women evolved well taking pill or other medications - oral naproxen-), and $61.3 \%$ were asymptomatic without taking any medication. The more interesting finding is that $88 \%$ of the patients in which CS was performed, with or without Anastrozole, were asymptomatic after 3 to 5 years without medication or reoperation, compared with only $21 \%$ if TUGPA was performed, with or without Anastrozole. Differences were significant between groups 1 and $2(p=0.004)$ and between groups 3 and $4(p=0.027)$, being equally significant $(p=0.019)$ in the four groups.

Post-hoc or sensitivity analyses. No pathology related to the treatments was observed throughout the CT follow-up period.

\section{Discussion}

Our study shows that oral administration of $1 \mathrm{mg} /$ day Anastrozole for 6 months, beginning before CS intervention of endometriosis, reduces or improves significantly the symptoms associated with the disease (especially dysmenorrhea and CPP) during and after treatment. No other significant advantages over the single insertion of LNG-IUD (Mirena $\left.{ }^{\circledR}\right)$, prior to CS, were observed. The recurrence and reoperation rates were similar at 2 years with or without Anastrozole that were adversely influenced by the performance of TUGPA. These findings clarify what was previously reported about the use of Anastrozole in the treatment of endometriosis, suggesting that the clinical benefits reported after 6 months (pain relief, see Table S1) are partly due to the associated medications and that there are no other additional benefits about the endometriosis itself and its clinical evolution [3,4,12-15].

Strengths and weaknesses of the study. The main strength of the study would be the strict randomization of cases of young women with endometriomas and elevated CA-125, for both patients taking or not Anastrozole and inclusion in CS or TUGPA during the medical treatment. However, a limitation of this research is the low number of cases included in the CT because of the low recruitment rate and the poor preliminary results observed in the interim in patients treated with TUGPA. We trusted that these patients would evolve as well as those who were treated with CS, because of the additional use of Anastrozole and Mirena ${ }^{\circledR}$, but it was not the case. However, the statistical tests are significant and, therefore, this is a valid CT that shows the poor results obtained performing TUGPA in endometriosis and which do not improve with the previous insertion of LNG-IUD (Mirena ${ }^{\circledR}$ ) and/or oral Anastrozole for 6 months. A possible bias in this study could be the use of vitamin $D(V D)$ in women taking Anastrozole, although the data on VD and endometriosis are controversial $[16,17]$.

Discussion of the findings in relation to other studies. Initial studies and CTs had described the Als as promising therapeutic agents for treatment of endometriosis [2,4] since they could suppress the local 
estrogen produced by aromatase-positive implants and subsequent proliferative effect, as well as blocking the action on COX-2 and prostaglandin E2, the latter being responsible for inflammation $[7,18]$. However, in most of these studies the use of Als (Anastrozole or Letrozole) was associated with OCP or $\mathrm{GnRH}$ analogues, so its beneficial effects could correspond to these other medications or their association, rather than to the Als themselves. Other case reports, series and prospective CTs using mainly Letrozole associated with noretindrone acetate (NETA) or OCP, compared to the use of the OCP or NETA alone [14,15], have been published after 2008 (see Table S1). Results do not show significant clinical advantages, but more cost and side effects related to the administration of Letrozole. Anastrozole was used only in 3 patients [19] with improvement of CPP and minimal side effects. Systematic reviews $[20,21]$ seem to conclude that Al may have a place in endometriosis treatment, but there is no clear evidence of improvement in endometriosis-associated infertility [22]; and the Committee Opinion No. 663 on Aromatase Inhibitors in gynecologic practice [23] pointed that Al are a promising therapeutic option that may be useful for the management of endometriosis-associated pain in a combined therapy with progestins.

The pathogenesis of endometriosis remains controversial. A recent and extensive review on it [24] shows that the innate ability of endometrial stem cells to regenerate cyclically seems to play a key role in the development of endometriosis, but also the dysregulated hormonal pathways. A genetic dysregulation would cause aberrant placement of those stem cells, and then immune cells, adhesion molecules, extracellular matrix metalloproteinase, and pro-inflammatory cytokines activate / alter the peritoneal microenvironment, creating the conditions for differentiation, adhesion, proliferation and survival of ectopic endometrial cells [25]. But in addition, the intracellular production of estrogens in these cells probably can also favour the development of the disease. Aromatase P450 (enzyme that catalyzes the conversion of androgens into estrogens) has been found both in endometriotic tissue as in the eutopic endometrium of women with endometriosis $[6,26]$, and in endometriosis, there is also a deficiency of $17 \beta$ -

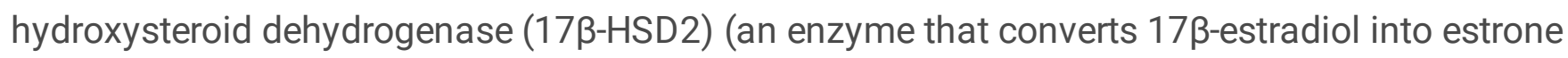
modulating exposure to the action of estrogens [27]. So that both the local production of estrogens and the loss of protective mechanisms determine a higher level of estradiol that characterizes both endometriosis and the eutopic endometrium of affected women [24]. Dislocated basal endometrial fragments in the peritoneal cavity can now induce chronic inflammation and tissue injury and repair (TIAR) mechanisms, which activate local estrogen production, proliferation, and infiltrative growth leading to endometriosis [28]. Later, the high concentration of estrogens and the overexpression of ER $\beta$ favor the survival and development of ER-positive ectopic tissue. Progesterone resistance is also a characteristic of endometriotic tissue compared to eutopic endometrium [29], and it is caused by the down-regulation of the progesterone receptor (PR ) in ectopic tissue [30,31]. Progesterone action is crucial to decreasing inflammation in the endometrium, and deviant progesterone signaling results in a proinflammatory phenotype which favours the establishment of ectopic endometrial implants.

In any case, when we proposed this prospective study to assess the efficacy of Anastrozole in endometriosis, we decided to associate it with the intrauterine insertion of an IUD containing LNG (for contraception and for a continued release of progestin). Previously Vercellini et al. [32] had published a 
pilot study using LNG-IUD versus expectant management after CS for symptomatic endometriosis with significant reduction of dysmenorrhea and risk of recurrence. Subsequently, other studies [9,33-40] have also shown that LNG-IUD is an effective and well accepted treatment to reduce dyspareunia and dysmenorrhea and increase quality of life in women with suspected endometriosis. However, the longterm maintenance therapy using LNG-IUD after surgery was not effective for preventing endometrioma recurrence [38]. These evidences agree with our prospective CT that shows a greater improvement of the painful symptoms and a certain time delay in the occurrence of recurrence in patients taking Anastrozole (with Calcium + VD simultaneously), although there were no clear significant differences with the group of no Anastrozole or other positive efficacy data in the administration of Anastrozole associated with Mirena ${ }^{\circledR}$ (versus only Mirena ${ }^{\circledR}$ ). The tumor marker levels were normalized more clearly in the patients who did not take Anastrozole and the rates of recurrence and reoperations were similar. The worst result in short and long term was the performance of TUGPA (instead of CS), independently of the use of Anastrozole and Mirena ${ }^{\circledR}$.

Therefore, despite the fact that sometimes medical therapy (either Anastrozole/Mirena ${ }^{\circledR}$, or Dienogest [41]) is sufficient to reduce the symptoms and signs of endometriosis, in a large number of patients it is necessary surgical eradication of lesions. In cases with intestinal deep infiltrating endometriosis, some authors $[42,43]$ propose its complete eradication with a nerve and vascular preserving approach to restore normal pelvic anatomy and its functions.

\section{Conclusions}

Anastrozole for 6 months, beginning before CS of endometriosis, improves significantly the painful symptoms of endometriosis but it has no other significant advantages over the single insertion of LNGIUD (Mirena ${ }^{\circledR}$ ) during that same time period. LNG-IUD (Mirena ${ }^{\circledR}$ ) associated with CS reduces significantly dysmenorrhea and dyspareunia, normalizes more effectively the values of CA-125, and also seems to decrease the rate of recurrences and long-term reoperations. However, Anastrozole / Mirena ${ }^{\circledR}$ associated with TUGPA are not very effective, so we deduce that these medications without surgery do not cure or significantly improve endometriosis itself.

Future research directions should be focused on the observation of subsequent fertility, as well as to the long-term recurrences in a greater number of cases operated with CS after previous insertion of Mirena ${ }^{\circledR}$, which could be maintained for 6-12 months, and even indefinitely, if patients do not want to get pregnant.

\section{Abbreviations}

$\mathrm{Al}$, aromatase inhibitors; $\mathrm{Cl}$, confidence interval; $\mathrm{CPP}$, chronic pelvic pain; $\mathrm{CS}$, conservative surgery; $\mathrm{CT}$, clinical trial; GnRH, gonadotropin-releasing hormone; LNG, levonorgestrel; LNG-IUD, levonorgestrelreleasing intrauterine device; OCP, oral contraceptive pill; SD, standard deviation; TUGPA, transvaginal ultrasound-guided puncture-aspiration; TVU, transvaginal ultrasound; VAS, visual analogue scale; 


\section{Declarations}

Statement: This study adheres to CONSORT guidelines and include a completed CONSORT checklist as an additional file.

Ethics approval and consent to participate: All subjects gave their informed consent for inclusion before they participated in the study. The study was conducted in accordance with the Declaration of Helsinki. And the protocol was approved by the Ethics Committee of San Juan University Hospital $(26 / 08 / 2008)$. It was registered in the Eudra CT System of the European Medicines Agency (London, 29-Sept-2008; No EudraCT: 2008-005744-17) (07/11/2008) and then authorized by the Spanish Agency for Medicines and Health Products (AEMPS) (10/11/2008).

Consent to participate: Written informed consent was obtained from all individual participants included in the study.

Consent for publication: Written consent for publication of data was obtained from all individual participants included in the study.

Availability of data and material: available. Code availability: SPSS fichas-endom-ensayo-casosanastrozol AROM-total31-dic18

Competing interest: We declare no competing interests. Not applicable.

Funding: This study was funded by the 'Fondo de Investigaciones Sanitarias', FIS PI07/0417, and PI10/01815. Ministry of Health, Madrid, Spain. Role of the funding source: "The funder of the study had no role in study design, data collection, data analysis, data interpretation, or writing of the report. The corresponding author had full access to all the data in the study and had final responsibility for the decision to submit it for publication."

Authors' contributions: P. Acién was the principal investigator in the FIS project and clinical trial, designed the study, made the review, tables and figures, and wrote the manuscript. I.Velasco participated in the FIS project and clinical trial as well as in the revision of the cases with endometriosis and reviewed the manuscript. M.Acién participated in the FIS project and clinical trial as well as in the revision of the cases with endometriosis, helped with the bibliographic search and reviewed the manuscript. PA had full access to all of the data in the study and took responsibility for the integrity of the data and the accuracy of the data analysis. All authors have read and approved the manuscript.

Authors Agreement. The authors verify that the submitted material has not been published and is not currently submitted for publication elsewhere. We agree (i) to the inclusion of our names as authors on the manuscript; (ii) to the order in which our names are shown on the title page of the manuscript; (iii) that all persons listed as authors fulfil the International Committee of Medical Journal Editors (ICMJE) criteria for authorship; and (iv) that no persons who fulfil the ICMJE criteria for authorship have been omitted from the author list. 
Acknowledgments:

- To all the doctors who collaborated in the project FIS-PI10-01815 (in addition to the authors who signed the study): Quereda-Seguí FJ, Martínez-Beltrán M, Chelea I, Fernández-Gálvez F, Abad-Gran M, MayolBelda MJ, Rueda-Puente J, Gutiérrez-Terán M, Caparrós-Cayuela E and Campos-Ferrer A. And to those who are part of the Research Collaborative Group FISABIO/Sant Joan d'Alacant University Hospital (in addition to those cited): Gascón-Castillo J, Montesinos-Llorca L, Rodríguez-Celdrán JM, Ruiz-Maciá E and Santoyo-Albert T.

- To collaborators in the Pharmacy Service of San Juan University Hospital: Aznar MT and Camacho MD.

- To Professor F. R. Reinoso for his advice and revision of the manuscript.

- To statistical advisor: Quesada-Rico JA.

\section{References}

1. Acién P, Velasco I, Acién M, Quereda F. Treatment of endometriosis with transvaginal ultrasoundguided drainage and recombinant interleukin-2 left in the cysts: a third clinical trial. Gynecol Obstet Invest. 2010;69:203-211. https://doi.org/10.1159/000270901

2. Bulun SE, Zeitoun KM, Takayama K, Sasano H. Molecular basis for treating endometriosis with aromatase inhibitors. Hum Reprod Update. 2000;6:413-18. https://doi.org/10.1093/humupd/6.5.413

3. Soysal S, Soysal ME, Ozer S, Gul N, Gezgin T. The effects of post-surgical administration of goserelin plus anastrozole compared to goserelin alone in patients with severe endometriosis: a prospective randomized trial. Hum Reprod. 2004;19:160-167. Doi: 10.1093/humrep/deh035.

4. Amsterdam LL, Gentry W, Jobanputra S, Wolf M, Rubin SD, Bulun SE. Anastrazole and oral contraceptives: a novel treatment for endometriosis. Fertil Steril. 2005;84:300-304. https://doi.org/10.1016/j.fertnstert.2005.02.018

5. Hefler LA, Grimm C, van Trotsenburg M, Nagele F. Role of the vaginally administered aromatase inhibitor anastrozole in women with rectovaginal endometriosis: a pilot study. Fertil Steril. 2005;84:1033-36. https://doi.org/10.1016/j.fertnstert.2005.04.059

6. Acién P, Velasco I, Gutiérrez M, Martínez-Beltrán M. Aromatase expression in endometriotic tissues and its relationship to clinical and analytical findings. Fertil Steril. 2007;88:32-38. https://doi.org/10.1016/j.fertnstert.2006.11.188

7. Tariverdian N, Theoharides TC, Siedentopf F, Gutiérrez G, Jeschke U, Rabinovich GA, et al. Neuroendocrine-immune disequilibrium and endometriosis: an interdisciplinary approach. Semin Immunopathol. 2007;29:193-210. https://doi.org/10.1007/s00281-007-0077-0

8. Velasco I, Acién P, Campos A, Acién MI, Ruiz-Maciá E. Interleukin- 6 and other soluble factors in peritoneal fluid and endometriomas and their relation to pain and aromatase expression. $J$ Reprod Immunol. 2010;84:199-205. https://doi.org/10.1016/j.jri.2009.11.004 
9. Petta CA, Ferriani RA, Abrao MS, Hassan D, Rosa e Silva JC, Podgaec S, Bahamondes L. Randomized clinical trial of a levonorgestrel-releasing intrauterine system and a depot $\mathrm{GnRH}$ analogue for the treatment of chronic pelvic pain in women with endometriosis. Hum Reprod. 2005;20:1993-98. https://doi.org/10.1093/humrep/deh869

10. Acién P, Quereda FJ, Gómez-Torres MJ, Bermejo R, Gutierrez M. GnRH analogues, transvaginal ultrasound-guided drainage and intracystic injection of recombinant Interleukin-2 in the treatment of endometriosis. Gynecol Obstet Invest. 2003;55:96-104. https://doi.org/10.1159/000070181

11. Acién P, Pérez-Albert G, Quereda FJ, Sanchez-Ferrer M, García-Almela A, Velasco I. Treatment of endometriosis with transvaginal ultrasound-guided drainage under $\mathrm{GnRH}$ analogues and recombinant Interleukin-2 left in the cysts. Gynecol Obstet Invest. 2005;60:224-231. https://doi.org/10.1159/000089100

12. Ailawadi RK, Jobanputra S, Kataria M, Gurates B, Bulun SE. Treatment of endometriosis and chronic pelvic pain with letrozole and norethindrone acetate: a pilot study. Fertil Steril. 2004;81:290-96. https://doi.org/10.1016/j.fertnstert.2003.09.029

13. Remorgida V, Abbamonte LH, Ragni N, Fulcheri E, Ferrero S. Letrozole and desogestrel-only contraceptive pill for the treatment of stage IV endometriosis. Aust N Z J Obstet Gynaecol. 2007;47:222-25. DOI: 10.1111/j.1479-828X.2007.00722.x

14. Ferrero S, Camerini G, Ragni N, Venturini PL, Biscaldi E, Seracchioli R, RemorgidaV. Letrozole and norethisterone acetate in colorectal endometriosis. Eur J Obstet Gynecol Reprod Biol. 2010;150:199202. https://doi.org/10.1016/j.ejogrb.2010.02.023

15. Ferrero S, Remorgida V, Venturini PL, Maggiore ULR. Norethisterone acetate versus norethisterone acetate combined with letrozole for the treatment of ovarian endometriotic cysts: a patient preference study. Eur J Obstet Gynecol Reprod Biol. 2014;174:117-122. https://doi.org/10.1016/j.ejogrb.2013.11.030

16. Somigliana E, Panina-Bordignon P, Murone S, Di Lucia P, Vercellini P, Vigano P. Vitamin D reserve is higher in women with endometriosis. Hum Reprod. 2007;22:2273-78. https://doi.org/10.1093/humrep/dem142

17. Miyashita M, Koga K, Izumi G, Sue F, Makabe T, Taguchi A, etal. Effects of 1,25-Dihydroxy Vitamin D3 on Endometriosis. J Clin Endocrinol Metab. 2016;101:2371-79. https://doi.org/10.1210/jc.2016-1515

18. 18. Attar E, Bulun SE. Aromatase inhibitors: the next generation of therapeutics for endometriosis?. Fertil Steril. 2006;85:1307-18. https://doi.org/10.1016/j.fertnstert.2005.09.064

19. Verma A, Konje JC. Successful treatment of refractory endometriosis-related chronic pelvic pain with aromatase inhibitors in premenopausal patients. Eur J Obstet Gynecol Reprod Biol. 2009;143:112-15. https://doi.org/10.1016/j.ejogrb.2008.12.002

20. Nothnick WB. The emerging use of aromatase inhibitors for endometriosis treatment. Reprod Biol Endocrinol. 2011;9:87. doi: 10.1186/1477-7827-9-87.

21. Pavone ME, Bulun SE. Aromatase inhibitors for the treatment of endometriosis: A review. Fertil Steril. 2012;98:1370-79. https://doi.org/10.1016/j.fertnstert.2012.08.053

Page $13 / 27$ 
22. Hashim HA. Aromatase inhibitors for endometriosis-associated infertility; do we have sufficient evidence?. Int J Fertil Steril. 2016;10:270-77. doi: 10.22074/ijfs.2016.5040

23. Committee Opinion No. 663. Aromatase inhibitors in gynecologic practice. Obstet Gynecol. 2016;127:e170-174.

24. Laganà AS, Garzon S, Götte M, Viganò P, Franchi M, Ghezzi F, Martin D. The Pathogenesis of Endometriosis: Molecular and Cell Biology Insights. Int J Mol Sci. 2019;20(22):5615. doi: 10.3390/ijms20225615.

25. Laganà AS, Vitale SG, Salmeri FM, Triolo $O$, Ban Frangež H, Vrtačnik-Bokal E, et al. Unus pro omnibus, omnes pro uno: A novel, evidence-based, unifying theory for the pathogenesis of endometriosis. Med Hypotheses. 2017;103:10-20. doi: 10.1016/j.mehy.2017.03.032.

26. Noble LS, Simpson ER, Johns A, Bulun SE. Aromatase Expression in Endometriosis. J Clin Endocrinol Metab. 1996;81:174-179. https://doi.org/10.1210/jcem.81.1.8550748.

27. Zeitoun K, Takayama K, Sasano H, Suzuki T, Moghrabi N, Andersson S, et al. Deficient 17ßHydroxysteroid Dehydrogenase Type 2 Expression in Endometriosis: Failure to Metabolize 17 $\beta$ Estradiol. J Clin Endocrinol Metab. 1998;83:4474-4480. https://doi.org/10.1210/jcem.83.12.5301.

28. Leyendecker G, Wildt L, Mall G. The pathophysiology of endometriosis and adenomyosis: Tissue injury and repair. Arch Gynecol Obstet. 2009;280:529-538. https://doi.org/10.1007/s00404-0091191-0.

29. Patel BG, Rudnicki M, Yu J, Shu Y, Taylor RN. Progesterone resistance in endometriosis: Origins, consequences and interventions. Acta Obstet Gynecol Scand. 2017;96:623-632. https://doi.org/10.1111/aogs.13156.

30. McKinnon B, Mueller M, Montgomery G. Progesterone Resistance in Endometriosis: An Acquired Property?. Trends Endocrinol Metab. 2018;29:535-548. https://doi.org/10.1016/j.tem.2018.05.006.

31. Bulun SE, Cheng Y-H, Yin P, Imir G, Utsunomiya H, Attar E, et al. Progesterone resistance in endometriosis: Link to failure to metabolize estradiol. Mol Cell Endocrinol. 2006;248:94-103. https://doi.org/10.1016/j.mce.2005.11.041.

32. Vercellini P, Frontino G, De Giorgi O, Aimi G, Zaina B, Crosignani PG. Comparison of a levonorgestrelreleasing intrauterine device versus expectant management after conservative surgery for symptomatic endometriosis: a pilot study. Fertil Steril. 2003;80:305-09. https://doi.org/10.1016/S0015-0282(03)00608-3

33. Gomes MKO, Ferriani RA, Rosa e Silva JC, Japur de Sá Rosa e Silva AC, Vieira CS, Cândido dos Reis FJ. The levonorgestrel-releasing intrauterine system and endometriosis staging. Fertil Steril. 2007;87:1231-34. https://doi.org/10.1016/j.fertnstert.2006.11.044

34. Wong AY, Tang LC, Chin RK. Levonorgestrel-releasing intrauterine system (Mirena) and Depot medroxyprogesterone acetate (Depoprovera) as long-term maintenance therapy for patients with moderate and severe endometriosis: a randomized controlled trial. Aust N Z J Obstet Gynaecol. 2010;50:273-79. https://doi.org/10.1111/j.1479-828X.2010.01152.x 
35. Tanmahasamut $P$, Rattanachaiyanont $M$, Angsuwathana $S$, Techatraisak K, Indhavivadhana $S$, Leerasiri P. Postoperative levonorgestrel-releasing intrauterine system for pelvic endometriosisrelated pain: a randomized controlled trial. Obstet Gynecol. 2012;119:519-26. doi: 10.1097/AOG.0b013e31824264c3

36. Cho S, Jung JA, Lee Y, Kim HY, Seo SK, Choi YS, et al. Postoperative levonorgestrel-releasing intrauterine system versus oral contraceptives after gonadotropin-releasing hormone agonist treatment for preventing endometrioma recurrence. Acta Obstet Gynecol Scand. 2014;93:38-44. https://doi.org/10.1111/aogs.12294|

37. Kim ML, Cho YJ, Kim MK, Jung YW, Yun BS, Seong SJ. The efficacy of long-term maintenance therapy with a levonorgestrel-releasing intrauterine system for prevention of ovarian endometrioma recurrence. Int J Gynaecol Obstet. 2016;134:256-59. https://doi.org/10.1016/j.ijgo.2016.03.017

38. Chen YJ, Hsu TF, Huang BS, Tsai HW, Chang YH, Wang PH. Postoperative maintenance levonorgestrel-releasing intrauterine system and endometrioma recurrence: a randomized controlled study. Am J Obstet Gynecol. 2017;216:582.e1-582.e9. https://doi.org/10.1016/j.ajog.2017.02.008

39. Kim MK, Chon SJ, Lee JH, Yun BH, Cho SH, Choi YS, et al. Postoperative Levonorgestrel-Releasing Intrauterine System Insertion After Gonadotropin-Releasing Hormone Agonist Treatment for Preventing Endometriotic Cyst Recurrence: A Prospective Observational Study. Reprod Sci. 2018;25:39-43. https://doi.org/10.1177/1933719117718274

40. Yucel N, Baskent E, Karamustafaoglu Balci B, Goynumer G. The levonorgestrel-releasing intrauterine system is associated with a reduction in dysmenorrhea and dyspareunia, a decrease in CA 125 levels, and an increase in quality of life in women with suspected endometriosis. Aust $\mathrm{N} Z \mathrm{~J}$ Obstet Gynaecol. 2018;58:560-63. doi: 10.1111/ajo.12773.

41. Laganà AS, Vitale SG, Granese R, Palmara V, Ban Frangež H, Vrtačnik-Bokal E, et al. Clinical dynamics of Dienogest for the treatment of endometriosis: from bench to bedside. Expert Opin Drug Metab Toxicol. 2017;13(6):593-596. doi: 10.1080/17425255.2017.1297421.

42. Laganà AS, Vitale SG, Trovato MA, Palmara VI, Chiara Rapisarda AM, Granese R, et al. Full-Thickness Excision versus Shaving by Laparoscopy for Intestinal Deep Infiltrating Endometriosis: Rationale and Potential Treatment Options. Biomed Res Int. 2016;2016:3617179. doi: 10.1155/2016/3617179.

43. Raffaelli R, Garzon S, Baggio S, Genna M, Pomini P, Laganà AS, et al. Mesenteric vascular and nerve sparing surgery in laparoscopic segmental intestinal resection for deep infiltrating endometriosis. Eur J Obstet Gynecol Reprod Biol. 2018;231:214-219. doi: 10.1016/j.ejogrb.2018.10.057.

\section{Tables}


Table 1

Baseline characteristics of the patients included in the Clinical Trial.

\begin{tabular}{|c|c|c|c|c|}
\hline Characteristics & $\begin{array}{l}\text { G1. Anastrozol + } \\
\text { LNGIUD + CS }(n=8)\end{array}$ & $\begin{array}{l}\text { G2. Anastrozol + LNGIUD } \\
+ \text { TUGPA }(n=7)\end{array}$ & $\begin{array}{l}\text { G3. } \\
\text { LNGIUD + } \\
\text { CS }(n=9)\end{array}$ & $\begin{array}{l}\text { G4. LNGIUD + } \\
\text { TUGPA }(n=7)\end{array}$ \\
\hline Age $(y)$ & $30.7 \pm 7.3(21-40)$ & $31.0 \pm 5.6(24-40)$ & $\begin{array}{l}33.6 \pm 4.0 \\
(26-40)\end{array}$ & $\begin{array}{l}30.4 \pm 8.2(20- \\
40)\end{array}$ \\
\hline Parity $\geq 1$ & $3(37.5 \%)$ & $1(14.3 \%)$ & $5(55.5 \%)$ & $0-$ \\
\hline Infertility & $0-$ & $1(14.3 \%)$ & $1(11.1 \%)$ & $1(14.3 \%)$ \\
\hline $\begin{array}{l}\text { Antecedents: } \\
\text { a.Endometriosis, MST }\end{array}$ & $1(12.5 \%)$ & $1(14.3 \%)$ & $2(22.2 \%)$ & $2(28.6 \%)$ \\
\hline $\begin{array}{l}\text { b.Endometriosis + } \\
\text { myomas }\end{array}$ & $1(12.5 \%)$ & $1(14.3 \%)$ & $0-$ & $0-$ \\
\hline c.Endometriosis-OCP & $0-$ & $1(14.3 \%)$ & $0-$ & $2(28.6 \%)$ \\
\hline Symptoms: VAS/10 & $5.6 \pm 1.6(3-8)$ & $6.1 \pm 2.0(4-9)$ & $\begin{array}{l}5.6 \pm 2.2(3 \\
9)\end{array}$ & $4.7 \pm 2.1(3-8)$ \\
\hline Dysmenorrhea/3 & $2.1 \pm 0.2(2-2.5)$ & $2.1 \pm 0.6(1.5-3)$ & $\begin{array}{l}1.7 \pm 0.6 \\
(0.5-2)\end{array}$ & $\begin{array}{l}1.8 \pm 0.9(0.5- \\
2.5)\end{array}$ \\
\hline Dyspareunia/3 & (7) $1.1 \pm 0.9(0.5-3)$ & $1.6 \pm 1.1(0-3)$ & $\begin{array}{l}1.4 \pm 1.0(0 \\
3)\end{array}$ & (4) $0.9 \pm 1.0(0-2)$ \\
\hline $\mathrm{CPP} / 3$ & $1.7 \pm 0.9(0-2.5)$ & $1.4 \pm 0.8(0.5-2.5)$ & $\begin{array}{l}1.7 \pm 1.0(0 \\
3)\end{array}$ & $1.8 \pm 1.5(0-3)$ \\
\hline $\begin{array}{l}\text { Trasvaginal US/ovaries: } \\
\text { a.endometriomas, RO }\end{array}$ & $2(25 \%)$ & $0-$ & $4(44.4 \%)$ & $0-$ \\
\hline b.endometriomas LO & $2(25 \%)$ & $3(42.8 \%)$ & $2(22.2 \%)$ & $5(71.4 \%)$ \\
\hline $\begin{array}{l}\text { c.bilateral/kissing } \\
\text { ovaries/rvs. }\end{array}$ & $4(50 \%)$ & $4(57.1 \%)$ & $3(33.3 \%)$ & $2(28.6 \%)$ \\
\hline
\end{tabular}

Data are $\mathrm{n}(\%)$, mean \pm standard desviation (SD) and (min-max) values. TUGPA, transvaginal ultrasoundguided puncture-aspiration; CS, conservative surgery; MST, previous medical and surgical treatment; OCP, oral contraceptive pill; VAS, visual analogic scale; CPP, chronic pelvic pain; RO, right ovary; LO, left ovary; endomet, endometriosis; rvs, recto-vaginal septum. 


\begin{tabular}{|c|c|c|c|c|}
\hline Characteristics & $\begin{array}{l}\text { G1. Anastrozol + } \\
\text { LNGIUD + CS }(n=8)\end{array}$ & $\begin{array}{l}\text { G2. Anastrozol + LNGIUD } \\
+ \text { TUGPA }(n=7)\end{array}$ & $\begin{array}{l}\text { G3. } \\
\text { LNGIUD + } \\
\text { CS }(n=9)\end{array}$ & $\begin{array}{l}\text { G4. LNGIUD + } \\
\text { TUGPA }(n=7)\end{array}$ \\
\hline $\begin{array}{l}\text { Analysis: } \\
\text { CA-125 }\end{array}$ & $80.5 \pm 57.8(36-190)$ & $90.4 \pm 37.6(37-150)$ & $\begin{array}{l}56.3 \pm 12.9 \\
(36-70.4)\end{array}$ & $87 \pm 42(53-168)$ \\
\hline CA-19-9 & $44.9 \pm 63.5(9.5-198)$ & (6) $58.9 \pm 71(2-191)$ & $\begin{array}{l}(8) 38 \pm 19.4 \\
(11-66)\end{array}$ & $\begin{array}{l}\text { (6) } 36.6 \pm 37(11- \\
111)\end{array}$ \\
\hline $\begin{array}{l}\text { Diagnosis: } \\
\text { a.endometrioma, RO }\end{array}$ & $1(12.5 \%)$ & $0-$ & $3(33.3 \%)$ & $0-$ \\
\hline b.endometrioma, LO & $1(12.5 \%)$ & $3(42.8 \%)$ & $2(22.2 \%)$ & $4(57.1 \%)$ \\
\hline c.pelvic endometriomas & $6(75 \%)$ & $4(57.1 \%)$ & $3(33.3 \%)$ & $3(42.8 \%)$ \\
\hline d.recurrent endomet/rvs & $0-$ & $0-$ & $1(11.1 \%)$ & $0-$ \\
\hline $\begin{array}{l}\text { Surgery. } \\
\text { a.TUGPA }\end{array}$ & $0-$ & $7(100)$ & $0-$ & $7(100)$ \\
\hline b.laparoscopy, CS & $7(87.5 \%)$ & $0-$ & $6(66.7 \%)$ & $0-$ \\
\hline c.laparotomy, CS & $1(12.5 \%)$ & $0-$ & $3(33.3 \%)$ & $0-$ \\
\hline $\begin{array}{l}\text { Findings in CS: } \\
\text { a.endometriomas }\end{array}$ & $4(50 \%)$ & - & $5(55.5 \%)$ & - \\
\hline $\begin{array}{l}\text { b.Severe pelvic endomet } \\
+ \text { end-omas }\end{array}$ & $3(37.5 \%)$ & - & $4(44.4 \%)$ & - \\
\hline $\begin{array}{l}\text { c.endometriomas + } \\
\text { myoma }\end{array}$ & $1(12.5 \%)$ & - & $0-$ & - \\
\hline $\begin{array}{l}\text { Histopathology. } \\
\text { a.cytology compatible } \\
\text { with endometriosis }\end{array}$ & - & $7(100)$ & - & $7(100)$ \\
\hline b.endometriosis (cystic) & $8(100)(1+$ Myo $)$ & $0-$ & $7(77.7 \%)$ & $0-$ \\
\hline
\end{tabular}




\begin{tabular}{|c|c|c|c|c|}
\hline Characteristics & $\begin{array}{l}\text { G1. Anastrozol + } \\
\text { LNGIUD + CS }(n=8)\end{array}$ & $\begin{array}{l}\text { G2. Anastrozol + LNGIUD } \\
+ \text { TUGPA }(n=7)\end{array}$ & $\begin{array}{l}\text { G3. } \\
\text { LNGIUD + } \\
\text { CS }(n=9)\end{array}$ & $\begin{array}{l}\text { G4. LNGIUD + } \\
\text { TUGPA }(n=7)\end{array}$ \\
\hline c.atypical endometriosis & $0-$ & $0-$ & $2(22.2 \%)$ & $0-$ \\
\hline
\end{tabular}


Table 2

Evolution of the primary efficacy variables in the 4 randomized groups of the Clinical Trial

\begin{tabular}{|lllllll|}
\hline Group Variable & Before & 3 months & 6 months & 9 months & 1 year & 2 years \\
& Treatment & $(\mathrm{DT})$ & $(\mathrm{DT})$ & $(3 \mathrm{~m} \mathrm{AT})$ & $(6 \mathrm{~m} \mathrm{AT})$ & $(1,5 y \mathrm{AT})$ \\
& $(\mathrm{N}), \mathrm{m} \pm \mathrm{SD}$ & $(\mathrm{N}), \mathrm{m} \pm \mathrm{SD}$ & $(\mathrm{N}), \mathrm{m} \pm \mathrm{SD}$ & $(\mathrm{N}), \mathrm{m} \pm \mathrm{SD}$ & $(\mathrm{N}), \mathrm{m} \pm \mathrm{SD}$ & $(\mathrm{N}), \mathrm{m} \pm \mathrm{SD}$ \\
& or $\mathrm{n}(\%)$ & or $\mathrm{n}(\%)$ & or $\mathrm{n}(\%)$ & or $\mathrm{n}(\%)$ & or $\mathrm{n}(\%)$ & or $\mathrm{n}(\%)$
\end{tabular}

\section{(1) Anastrozol + LNG-IUD}

\begin{tabular}{|c|c|c|c|c|c|c|}
\hline CS: $\quad V A S / 10$ & (8) $5.6 \pm 1.6$ & $\begin{array}{l}\text { (8) } 2.4 \pm \\
1.2^{\mathrm{a} 1 \mathrm{~b} 2 \mathrm{~d} 2}\end{array}$ & $\begin{array}{l}\text { (8) } 2.4 \pm \\
2.1^{\text {a1d } 1}\end{array}$ & $\begin{array}{l}\text { (8) } 2.3 \pm \\
1.3^{\mathrm{a} 1 \mathrm{~b} 2 \mathrm{~d} 2}\end{array}$ & $\begin{array}{l}\text { (8) } 2.6 \pm \\
1.6^{\mathrm{a} 1 \mathrm{~b} 2 \mathrm{~d} 1}\end{array}$ & $\begin{array}{l}\text { (8) } 2.4 \pm \\
1.6^{\mathrm{a} 1 \mathrm{~d} 1}\end{array}$ \\
\hline -dysmenorrhea & $2.1 \pm 0.2$ & $1.1 \pm$ & $0.6 \pm$ & $1 \pm 0.5^{\mathrm{a} 2 \mathrm{~b} 2 \mathrm{~d} 2}$ & $1.2 \pm$ & $1.1 \pm$ \\
\hline & & $0.7^{\mathrm{a} 1 \mathrm{~b} 1 \mathrm{~d} 1}$ & $0.8^{\mathrm{a} 1 \mathrm{~b} 1 \mathrm{~d} 2}$ & & $0.9^{\mathrm{a} 1 \mathrm{~b} 1 \mathrm{~d} 1}$ & $0.7^{\mathrm{a} 1 \mathrm{~b}}$ \\
\hline
\end{tabular}

-dyspareunia

(7) $1.1 \pm 0.9$

(7) $0.4 \pm 0.5$

(7) $0.6 \pm 1.1$

(7) $0.4 \pm$

(7) $0.9 \pm 1.8$

(7) $0.4 \pm 0.7$

$0.6^{\mathrm{a} 1 \mathrm{~b} 1 \mathrm{~d} 1}$

-CPP

$1.8 \pm 0.9$

$0.6 \pm$

$0.6 \pm$

$0.7 \pm$

$0.8 \pm$

$1.2 \pm 1.6$

$0.5^{\mathrm{a} 1 \mathrm{~b} 1 \mathrm{~d} 1}$

$0.4^{\mathrm{a} 1 \mathrm{~b} 1 \mathrm{~d} 1}$

$0.5^{\mathrm{a} 1 \mathrm{~b} 1 \mathrm{~d} 1}$

$0.5^{\mathrm{a} 1 \mathrm{~b} 1 \mathrm{~d} 1}$

TV ultras/ovaries:

$\begin{array}{lllllll}\text {-normal or } & - & 7(87.5) & 5(62.5) & 6(75) & 7(87.5) & 5(62.5)\end{array}$

dysfunctional

-simple cyst or

$1(12.5)$

$3(37.5)$

2(25)

$1(12.5)$

2(25)

small endomet

-endometriomas $8(100)$

$0-\mathrm{a} 2 \mathrm{~b} 2 \mathrm{~d} 2$

0 - ${ }^{2} \mathrm{~b} 2 \mathrm{~d} 2$

$0-{ }^{-2} 2 \mathrm{~b} 2 \mathrm{~d} 2$

0- ${ }^{2}$ b2d2

$1(12.5)^{\mathrm{a} 1 \mathrm{~b} 1 \mathrm{~d} 1}$

(rvs)

\section{Tumor markers:}
-CA-125
(8) $80.5 \pm$
(7) $19.5 \pm$
(8) $11.3 \pm$
(7) $24.2 \pm$
(7) $19.7 \pm$
(8) $19.5 \pm$
57.8
$10.9^{\mathrm{a} 1 \mathrm{~d} 1}$
$3.6^{\mathrm{a} 1 \mathrm{~b} 2 \mathrm{~d} 1}$
26.2
$10.5^{\mathrm{a} 1 \mathrm{~b} 1 \mathrm{~d} 1}$
$10.5^{\mathrm{a} 1 \mathrm{~b} 2 \mathrm{~d} 1}$

Data are $\mathrm{n}(\%)$, mean \pm standard desviation (SD). Nonparametric tests (for two related samples) between values before treatment and at $3 \mathrm{~m}, 6 \mathrm{~m}, 9 \mathrm{~m}, 1 \mathrm{y}$ and $2 \mathrm{y}$.- Test of ranges with Wilcoxon signs: $\mathrm{a} 1=\mathrm{p}<$ $0.05, a 2=p<0.01 ; a 3=p<0.001$. Signs test: $b 1=p<0.05, b 2=p<0.01, b 3=p<0.001$. Mc Nemar test (for dichotomous variants): $c 1=p<0.05, c 2=p<0.01 ; c 3=p<0.001$. Marginal homogeneity test: $d 1=p$ $<0.05, d 2=p<0.01, d 3=p<0.001$. Only significant results are indicated. DT, during treatment; AT, after treatment; CS, conservative surgery; TUGPA, transvaginal ultrasound-guided puncture-aspiration; VAS, visual analogic scale; CPP, chronic pelvic pain; TV ultras, transvaginal ultrasound; endomet, endometrioma; rvs, rectovaginal septum; op, operated. 


\begin{tabular}{|c|c|c|c|c|c|c|c|}
\hline \multirow[t]{3}{*}{ Group } & \multirow[t]{3}{*}{ Variable } & Before & 3 months & 6 months & 9 months & 1 year & 2 years \\
\hline & & Treatment & (DT) & (DT) & (3 m AT) & (6 m AT) & $(1,5 y$ AT) \\
\hline & & $\begin{array}{l}(\mathrm{N}), \mathrm{m} \pm \mathrm{SD} \\
\text { or } \mathrm{n}(\%)\end{array}$ & $\begin{array}{l}(\mathrm{N}), \mathrm{m} \pm \mathrm{SD} \\
\text { or } \mathrm{n}(\%)\end{array}$ & $\begin{array}{l}(\mathrm{N}), \mathrm{m} \pm \mathrm{SD} \\
\text { or } \mathrm{n}(\%)\end{array}$ & $\begin{array}{l}(\mathrm{N}), \mathrm{m} \pm \mathrm{SD} \\
\text { or } \mathrm{n}(\%)\end{array}$ & $\begin{array}{l}(\mathrm{N}), \mathrm{m} \pm \mathrm{SD} \\
\text { or } \mathrm{n}(\%)\end{array}$ & $\begin{array}{l}(\mathrm{N}), \mathrm{m} \pm \mathrm{SD} \\
\text { or } \mathrm{n}(\%)\end{array}$ \\
\hline & \multirow[t]{2}{*}{$-C A-19-9$} & (8) $44.9 \pm$ & (7) $10.9 \pm$ & (6) $6 \pm$ & (6) $17.2 \pm$ & (6) $12.7 \pm$ & (7) $18.7 \pm$ \\
\hline & & 63.5 & $8.6^{a 1}$ & $3.1^{\mathrm{a} 1 \mathrm{~b} 1}$ & $22.1^{\mathrm{a} 1}$ & $13.8^{\mathrm{b} 1}$ & 26.8 \\
\hline
\end{tabular}

(2) Anastrozole + LNG-IUD
$+\quad V A S / 10$ :
(7) $6.1 \pm 2$
(7) $3.1 \pm$
(7) $3.6 \pm$
(7) $4.9 \pm$
$\begin{array}{lll}\text { (5) } 3.6 \pm 1.1 & \text { (4) } 3.1 \pm 1\end{array}$

TUGPA:

$3.1^{\mathrm{a} 1 \mathrm{~d} 1} \quad 2.1^{\mathrm{a} 1 \mathrm{~b} 1 \mathrm{~d} 1} \quad 2.5^{\mathrm{a} 1 \mathrm{~d} 1}$

-dysmenorrhea

$2.1 \pm 0.6$

$0.5 \pm$

$0.6 \pm$

$1.4 \pm 0.4^{\mathrm{a} 1 \mathrm{~d} 1} 1.5 \pm 0.8$

$1.4 \pm 1$

$0.9^{\mathrm{a} 1 \mathrm{~b} 1 \mathrm{~d} 1} \quad 0.6^{\mathrm{a} 1 \mathrm{~b} 1 \mathrm{~d} 1}$

-dyspareunia

$1.6 \pm 1.1 \quad 0.9 \pm 1$

$1.1 \pm 1.1$

$1 \pm 1$

$0.5 \pm 0.4 \quad 0.4 \pm 0.2$

$-\mathrm{CPP}$

$1.4 \pm 0.8$

$0.8 \pm 0.9$

$1.4 \pm 1.1$

$1.5 \pm 1$

$1.1 \pm 0.7 \quad 0.8 \pm 0.5$

TV ultras/ovaries:

2 op (28.6) 3 op (42.9)

-normal or

1(14.3)

$0-$

$0-$

$0-$

$0-$

dysfunctional

-simple cyst or

3(42.9)

1(14.3)

1(14.3)

$0-$

$3(75)(42.9)$

small endomet

-endometriomas

$7(100)$

3(42.9)

6(85.7)

6(85.7)

5(100)(71.4) 1(25)(14.3)

(rvs)

\section{Tumor markers:}

\begin{tabular}{|c|c|c|c|c|c|}
\hline$-C A-125$ & $\begin{array}{l}\text { (7) } 90.4 \pm \\
37.6\end{array}$ & $\begin{array}{l}\text { (7) } 69.8 \pm \\
105.7\end{array}$ & $\begin{array}{c}\text { (7) } 74 \pm 70.9 \text { (6) } 63.9 \pm \\
31.1\end{array}$ & $\begin{array}{l}\text { (5) } 71.1 \pm \\
71.6\end{array}$ & $\begin{array}{l}\text { (4) } 50.6 \pm \\
36.1\end{array}$ \\
\hline
\end{tabular}

-CA-19-9

(6) $58.9 \pm 71$

$\begin{array}{ll}(7) 21.3 \pm & (6) 64.9 \pm \\ 16.5 & 100.8\end{array}$

(5) $29.8 \pm$

(4) $46 \pm 56.3$ (4) $17.5 \pm$

22.2

11.8

Data are $\mathrm{n}(\%)$, mean \pm standard desviation (SD). Nonparametric tests (for two related samples) between values before treatment and at $3 \mathrm{~m}, 6 \mathrm{~m}, 9 \mathrm{~m}, 1 \mathrm{y}$ and $2 \mathrm{y}$.- Test of ranges with Wilcoxon signs: $\mathrm{a} 1=\mathrm{p}<$ $0.05, a 2=p<0.01 ; a 3=p<0.001$. Signs test: $b 1=p<0.05, b 2=p<0.01, b 3=p<0.001$. Mc Nemar test (for dichotomous variants): $c 1=p<0.05, c 2=p<0.01 ; c 3=p<0.001$. Marginal homogeneity test: $d 1=p$ $<0.05, d 2=p<0.01, d 3=p<0.001$. Only significant results are indicated. DT, during treatment; AT, after treatment; CS, conservative surgery; TUGPA, transvaginal ultrasound-guided puncture-aspiration; VAS, visual analogic scale; CPP, chronic pelvic pain; TV ultras, transvaginal ultrasound; endomet, endometrioma; rvs, rectovaginal septum; op, operated. 


\begin{tabular}{|lllllll|}
\hline Group Variable & Before & 3 months & 6 months & 9 months & 1 year & 2 years \\
& Treatment & $(\mathrm{DT})$ & $(\mathrm{DT})$ & $(3 \mathrm{~m} \mathrm{AT})$ & $(6 \mathrm{~m} \mathrm{AT})$ & $(1,5 \mathrm{~A})$ \\
& & & & & \\
& $(\mathrm{N}), \mathrm{m} \pm \mathrm{SD})$ & $(\mathrm{N}), \mathrm{m} \pm \mathrm{SD}$ & $(\mathrm{N}), \mathrm{m} \pm \mathrm{SD}$ & $(\mathrm{N}), \mathrm{m} \pm \mathrm{SD}$ & $(\mathrm{N}), \mathrm{m} \pm \mathrm{SD}$ & $(\mathrm{N}), \mathrm{m} \pm \mathrm{SD}$ \\
& or $\mathrm{n}(\%)$ & or $\mathrm{n}(\%)$ & or $\mathrm{n}(\%)$ & or $\mathrm{n}(\%)$ & or $\mathrm{n}(\%)$ & or $\mathrm{n}(\%)$
\end{tabular}

(3) LNG-IUD, No Anastrozol

\begin{tabular}{|c|c|c|c|c|c|c|c|}
\hline$+C S$ & $V A S / 10$ & (9) $5.6 \pm 2.2$ & $\begin{array}{l}\text { (9) } 2.9 \pm \\
2^{\mathrm{a} 1 \mathrm{~d} 1}\end{array}$ & $\begin{array}{l}\text { (9) } 3.1 \pm \\
1.8^{\mathrm{a} 1 \mathrm{~d} 1}\end{array}$ & $\begin{array}{l}\text { (9) } 3.5 \pm \\
1.9^{\mathrm{a} 1 \mathrm{~b} 1 \mathrm{~d} 1}\end{array}$ & $\begin{array}{l}\text { (8) } 4 \pm \\
2^{\mathrm{a} 1 \mathrm{~b} 1 \mathrm{~d} 1}\end{array}$ & (6) $2.8 \pm 1.1$ \\
\hline & -dysmenorrhea & $1.7 \pm 0.6$ & $\begin{array}{l}0.8 \pm \\
0.7^{\mathrm{a} 1 \mathrm{~b} 1 \mathrm{~d} 1}\end{array}$ & $\begin{array}{l}0.8 \pm \\
0.7^{\mathrm{a} 1 \mathrm{~b} 2 \mathrm{~d} 1}\end{array}$ & $1.4 \pm 0.9$ & $1.5 \pm 1$ & (5) $1.3 \pm 1$ \\
\hline
\end{tabular}

-dyspareunia

$1.4 \pm 1$

(8) $0.8 \pm 1$

(8) $0.7 \pm$

(8) $0.7 \pm$

(7) $0.9 \pm$

(5) $0.4 \pm 0.5$

$0.5^{\mathrm{a} 1 \mathrm{~b} 1 \mathrm{~d} 1}$

$0.7^{\mathrm{a} 1 \mathrm{~b} 1 \mathrm{~d} 1}$

$0.7^{\mathrm{a} 1 \mathrm{~d} 1}$

-CPP

$1.7 \pm 1$

$0.8 \pm 0.9$

$1 \pm 0.7$

$0.8 \pm 0.8$

$1 \pm 1$

(5) $0.4 \pm 0.5$

TV ultras/ovaries:

$\begin{array}{llllll}\text {-normal or } \quad- & 8(88.9) & 8(88.9) & 5(55.6) & 5(62.5) & 3(50)\end{array}$

dysfunctional

-simple cyst or

$0-$

$1(11.1)$

1(11.1)

2(25)

2(33.3)

small endomet

-endometriomas $9(100)$

1(11.1)

$0-$

2(22.2)

1(12.5)

1(16.7)

(rvs)

\section{Tumor markers:}
-CA-125
(9) $56.3 \pm$
(8) $11.4 \pm$
(9) $12.4 \pm$
(9) $16 \pm$
(8) $16.7 \pm$
(6) $21.2 \pm$
12.9
$7.9^{\mathrm{a} 1 \mathrm{~b} 2}$
$8.9^{\mathrm{a} 2 \mathrm{~b} 2 \mathrm{~d} 2}$
$9.1^{\mathrm{a} 2 \mathrm{~b} 2 \mathrm{~d} 2}$
$10.8^{\mathrm{a} 1 \mathrm{~b} 2 \mathrm{~d} 2}$
$19^{\mathrm{a} 1 \mathrm{~b} 1 \mathrm{~d} 1}$
-CA-19-9
(8) $38 \pm 19.4$
(6) $10.2 \pm 4^{a 1}$
(8) $14.8 \pm$
$11.3^{\mathrm{a} 1 \mathrm{~d} 1}$
(8) $11.9 \pm$
(7) $12.1 \pm$
(6) $25.5 \pm$
$6.5^{\mathrm{a} 1 \mathrm{~b} 1 \mathrm{~d} 1}$
$6.8^{\mathrm{a} 1 \mathrm{~b} 1 \mathrm{~d} 1}$
22.2

Data are $\mathrm{n}(\%)$, mean \pm standard desviation (SD). Nonparametric tests (for two related samples) between values before treatment and at $3 \mathrm{~m}, 6 \mathrm{~m}, 9 \mathrm{~m}, 1 \mathrm{y}$ and $2 \mathrm{y}$.- Test of ranges with Wilcoxon signs: $\mathrm{a} 1=\mathrm{p}<$ $0.05, a 2=p<0.01 ; a 3=p<0.001$. Signs test: $b 1=p<0.05, b 2=p<0.01, b 3=p<0.001$. Mc Nemar test (for dichotomous variants): $c 1=p<0.05, c 2=p<0.01 ; c 3=p<0.001$. Marginal homogeneity test: $d 1=p$ $<0.05, d 2=p<0.01, d 3=p<0.001$. Only significant results are indicated. DT, during treatment; AT, after treatment; CS, conservative surgery; TUGPA, transvaginal ultrasound-guided puncture-aspiration; VAS, visual analogic scale; CPP, chronic pelvic pain; TV ultras, transvaginal ultrasound; endomet, endometrioma; rvs, rectovaginal septum; op, operated. 


\begin{tabular}{|lllllll|}
\hline Group Variable & Before & 3 months & 6 months & 9 months & 1 year & 2 years \\
& Treatment & $(\mathrm{DT})$ & $(\mathrm{DT})$ & $(3 \mathrm{~m} \mathrm{AT})$ & $(6 \mathrm{~m} \mathrm{AT})$ & $(1,5 \mathrm{AT})$ \\
& $(\mathrm{N}), \mathrm{m} \pm \mathrm{SD}$ & $(\mathrm{N}), \mathrm{m} \pm \mathrm{SD}$ & $(\mathrm{N}), \mathrm{m} \pm \mathrm{SD}$ & $(\mathrm{N}), \mathrm{m} \pm \mathrm{SD}$ & $(\mathrm{N}), \mathrm{m} \pm \mathrm{SD}$ & $(\mathrm{N}), \mathrm{m} \pm \mathrm{SD}$ \\
& or $\mathrm{n}(\%)$ & or $\mathrm{n}(\%)$ & or $\mathrm{n}(\%)$ & or $\mathrm{n}(\%)$ & or $\mathrm{n}(\%)$ & or $\mathrm{n}(\%)$ \\
& & & & &
\end{tabular}

(4) LNG-IUD, No Anastrozol
$+\quad V A S / 10$ :
(7) $4.6 \pm 2.2$ (7) $3.4 \pm 1.8$ (7) $3 \pm 1.3$
(7) $3.2 \pm 1.5$
(6) $3.6 \pm 1.6$
(2) $4.3 \pm 2.5$

TUGPA:

\begin{tabular}{|c|c|c|c|c|c|}
\hline -dysmenorrhea & $1.6 \pm 0.7$ & $1.4 \pm 0.9$ & $1.1 \pm 0.9$ & $1.4 \pm 0.6$ & $1.3 \pm 0.5$ \\
\hline -dyspareunia & (4) $0.9 \pm 1$ & (6) $0.3 \pm 0.4$ & (6) $0.3 \pm 0.4$ & (5) $0.2 \pm 0.4$ & $\begin{array}{ll}\text { (4) } 0.5 \pm 1 & \text { (1) } 2\end{array}$ \\
\hline$-\mathrm{CPP}$ & $1.6 \pm 1.1$ & $1.1 \pm 0.9$ & $1.1 \pm 0.9^{\mathrm{a} 1 \mathrm{~d} 1}$ & $0.9 \pm 0.7$ & $1.1 \pm 0.9$ \\
\hline TV ultras/ovaries: & & & & & $(1 \mathrm{op}, 14,3 \%)(3 \mathrm{op}, 42.9 \%)$ \\
\hline $\begin{array}{l}\text {-normal or } \\
\text { dysfunctional }\end{array}$ & - & $1(14.3)$ & $0-$ & $0-$ & $1(16.7)(14.3) 1(50)(14.3)$ \\
\hline $\begin{array}{l}\text {-simple cyst or } \\
\text { small endomet }\end{array}$ & - & $2(28.6)$ & $0-$ & $0-$ & $1(16.7)(14.3) 0-$ \\
\hline $\begin{array}{l}\text {-endometriomas } \\
\text { (rvs) }\end{array}$ & $7(100)$ & $4(57.1)$ & $7(100)$ & $7(100)$ & $4(66.7)(57.1) 1(50)(14.3)$ \\
\hline
\end{tabular}

\section{Tumor markers:}

$\begin{array}{lllllll}\text {-CA-125 } & \text { (7) } 87 \pm 42 & \begin{array}{l}\text { (7) } 26.9 \pm \\ \end{array} & (7) 26.6 \pm & (7) 42.2 \pm & \text { (6) } 43.2 \pm & \text { (2) } 51.7 \pm 3.4 \\ & & 18.1^{\mathrm{a} 1 \mathrm{~b} 1 \mathrm{~d} 1} & 21.9^{\mathrm{a} 1 \mathrm{~b} 1 \mathrm{~d} 1} & 37.8^{\mathrm{a} 1 \mathrm{~b} 1 \mathrm{~d} 1} & 24.2^{\mathrm{a} 1 \mathrm{~d} 1} & \\ \text {-CA-19-9 } & \text { (6) } 36.6 \pm & (5) 15.1 \pm & (6) 12.3 \pm & (5) 21.2 \pm & \text { (5) } 18.5 \pm & \text { (2) } 18.9 \pm \\ & 37.4 & 14.3 & 13^{\mathrm{a} 1} & 22.3 & 13.2 & 13.7\end{array}$

Data are $\mathrm{n}(\%)$, mean \pm standard desviation (SD). Nonparametric tests (for two related samples) between values before treatment and at $3 \mathrm{~m}, 6 \mathrm{~m}, 9 \mathrm{~m}$, 1y and $2 \mathrm{y}$.- Test of ranges with Wilcoxon signs: $\mathrm{a} 1=\mathrm{p}<$ $0.05, a 2=p<0.01 ; a 3=p<0.001$. Signs test: $b 1=p<0.05, b 2=p<0.01, b 3=p<0.001$. Mc Nemar test (for dichotomous variants): $c 1=p<0.05, c 2=p<0.01 ; c 3=p<0.001$. Marginal homogeneity test: $d 1=p$ $<0.05, d 2=p<0.01, d 3=p<0.001$. Only significant results are indicated. DT, during treatment; AT, after treatment; CS, conservative surgery; TUGPA, transvaginal ultrasound-guided puncture-aspiration; VAS, visual analogic scale; CPP, chronic pelvic pain; TV ultras, transvaginal ultrasound; endomet, endometrioma; rvs, rectovaginal septum; op, operated. 
Table 3

Fertility and clinical status in last control of the patients included in the clinical trial.

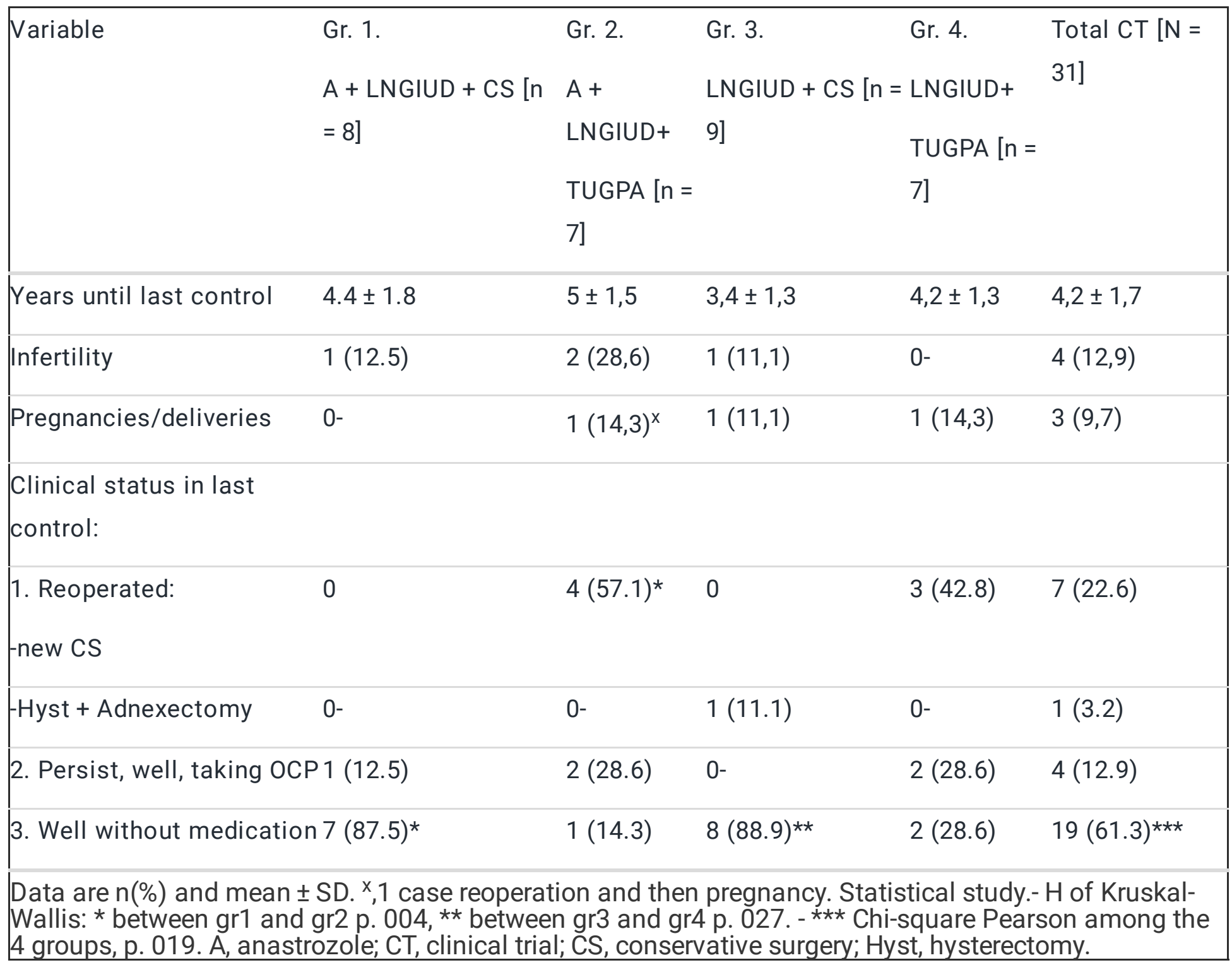

\section{Figures}




\section{CONSORT 2010 Flow Diagram}

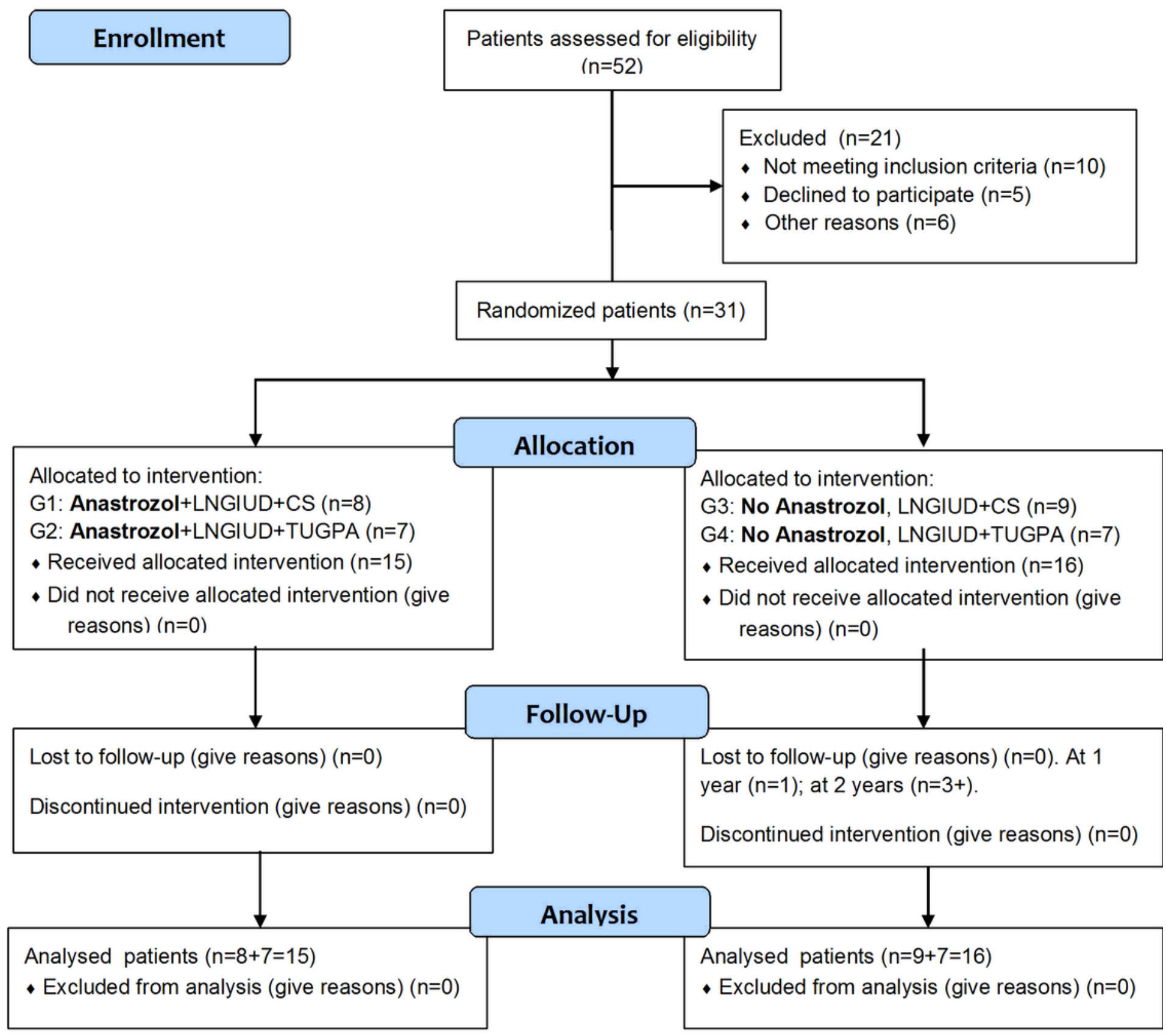

\section{Figure 1}

Trial profile 

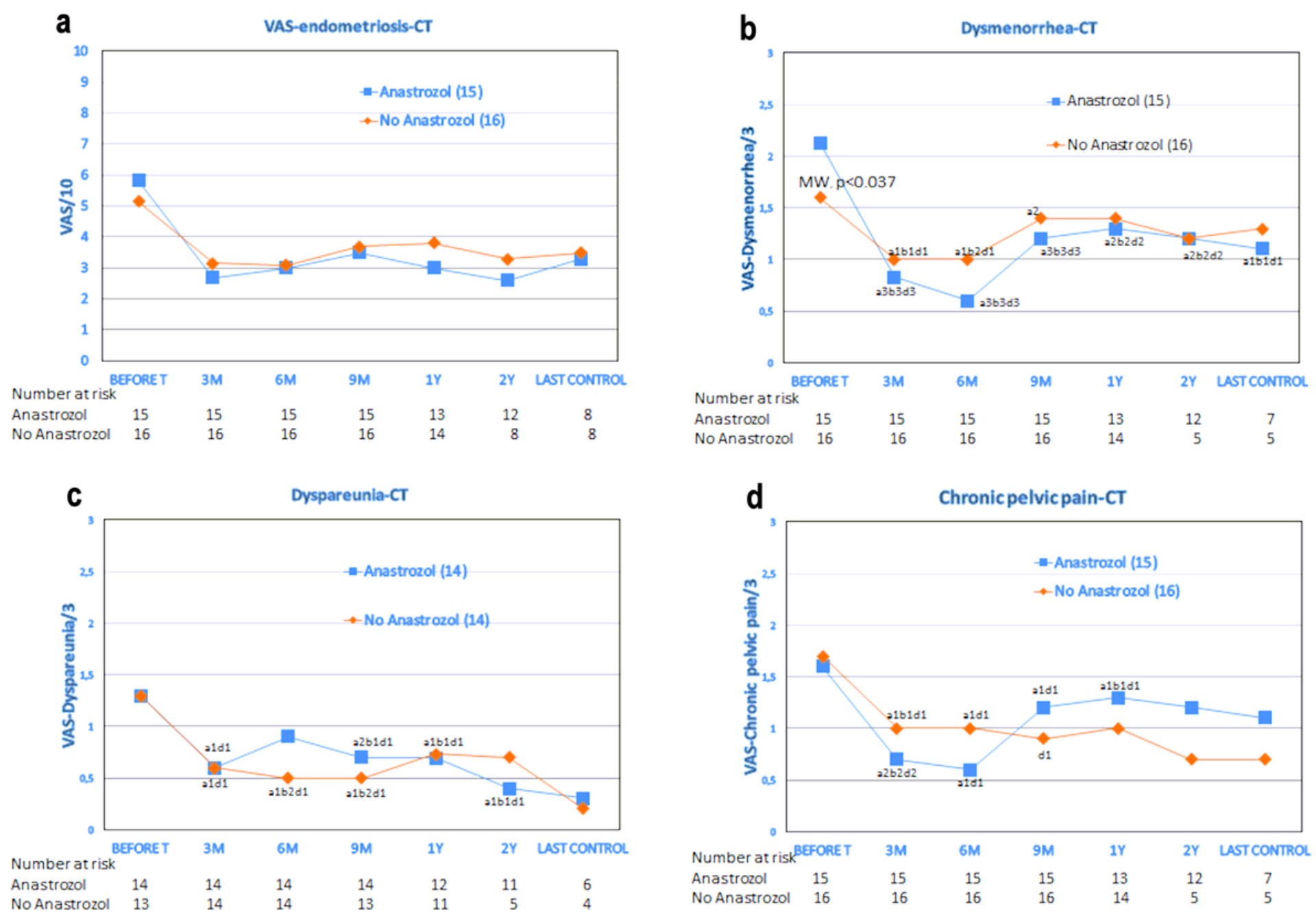

Figure 2

Evolution of the symptoms score in patients taking or not Anastrozole: a, VAS. b, Dysmenorrhea. c, Dyspareunia. d, Chronic pelvic pain. 

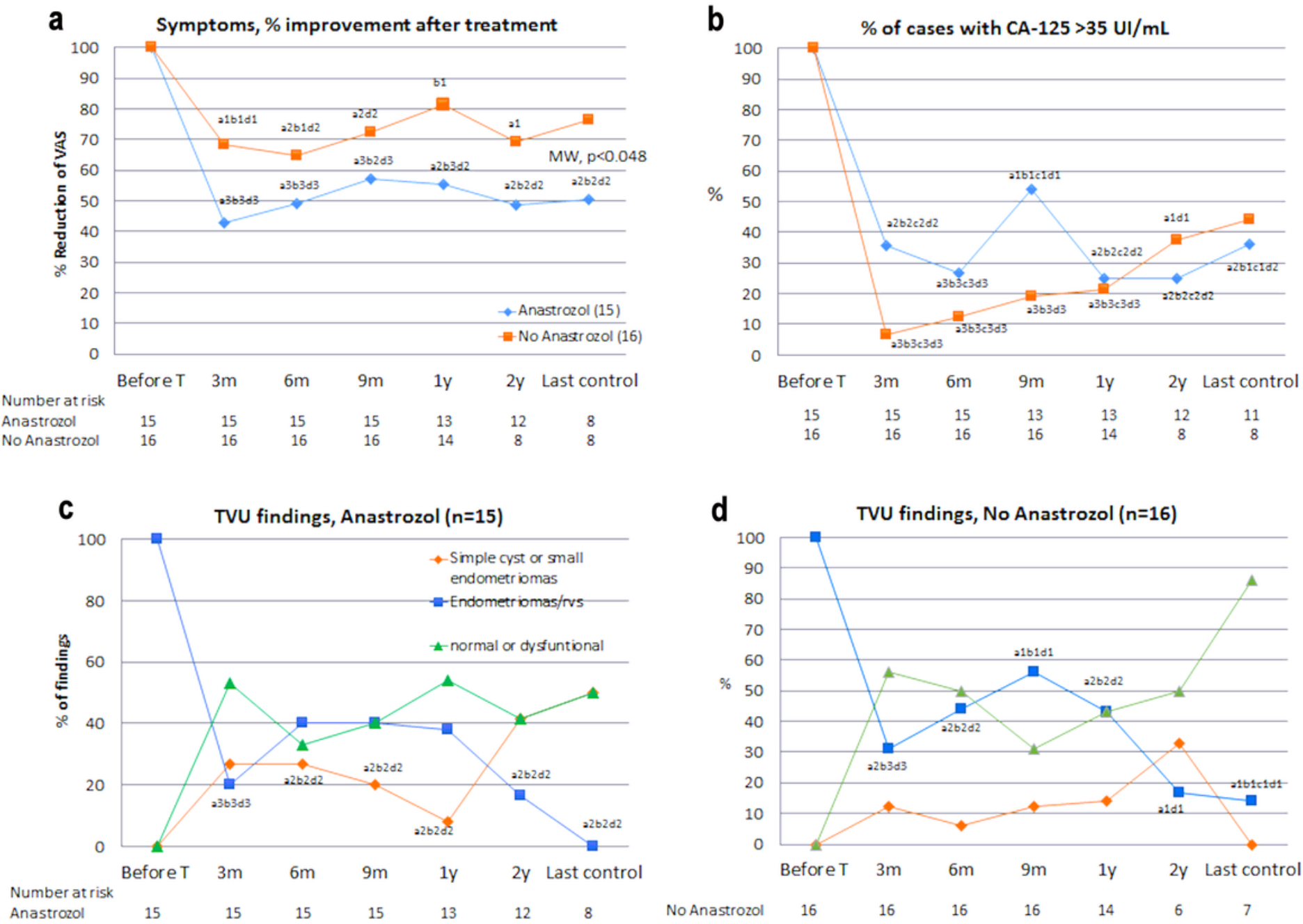

\section{Figure 3}

Evolution of the variables of primary efficacy taking or not Anastrozole: a, VAS, \% improvement by treatment. $b$, \% of cases with CA-125>35 UI/mL. c, Ultrasound finding (TVU) in the CT under Anastrozole (15 patients). d, Ultrasound finding (TVU) in the CT, no Anastrozole (16 patients). Normal or dysfunctional= findings of normal ovaries or with dysfunctional cyst (luteal). 


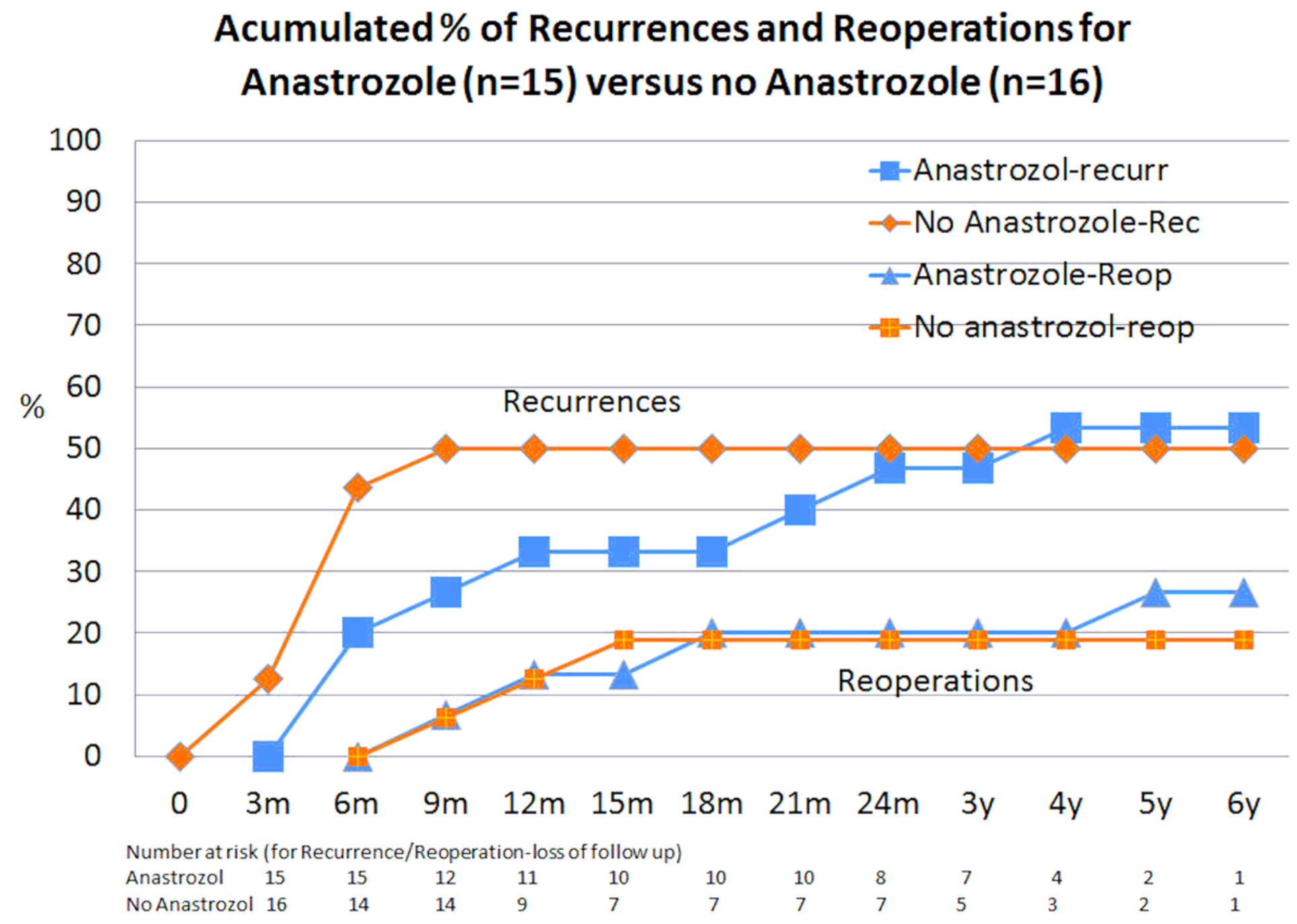

Figure 4

Accumulated \% of recurrences and reoperations for Anastrozole versus no Anastrozole.

\section{Supplementary Files}

This is a list of supplementary files associated with this preprint. Click to download.

- CONSORT2010ChecklistrevScRBMCWH.doc

- TableS1.publicationsrevIAromatasa.docx 